\title{
ANALISIS YURIDIS OTONOMI DAERAH BARBASIS KAPASITAS LOKAL (STUDI TETANG MODEL PENGELOLAAN KEUANGAN DAN ASET DAERAH KABUPATEN PUNCAK JAYA)
}

\author{
Suwignyo \\ Pemda Papua Barat \\ Suwignyo.mhiy@gmail.com
}

\begin{abstract}
Abstrak
$P$ enelitian ini berjudul analisis yuridis otonomi daerah berbasis Kapasitas Lokal, Studi Tentang Model Pengelolaan Keuangan dan Aset Daerah Kabupaten Puncak Jaya. Latarbelakang penelitian ini adalah Kabupaten Puncak Jaya mendapatkan otonomi khusus Papua, mendapatkan alokasi $80 \%$ dari dana otonomi khusus. Kabupaten Puncak Jaya juga memiliki sumber daya alam berlimpah, tetapi terjadi kelambatan dalam pembangunan. Faktor utama adalah system pembangunan tidak berbasis pada kapasitas local. Sudut pandang hukum tentang kapasitas local mengacu pada teori Friedmen tentang tiga system hukum, yaitu aspek legal substansi, legal struktur dan budaya hukum. Penelitan ini melihat secara komprehensif terhadap tiga bagian tersebut dalam ruang lingkup Kabupaten Puncak Jaya. Penelitan ini menggunakan pendekatan yuridis empiris dan teknisk analisis kualitatif, sumber data adalah peraturan perundang-undangan tentang pemerintahan daerah, keuangan daerah dan otonomi daerah, laporan pengelolahan daerah dari lembaga berwenang, wawancara dengan otoritas pemerintahan dan keuangan di Kabupaten Pucak Jaya. Melalui metode ini diperoleh hasil yang maksimal serta dapat dipertanggungjawabkan. Undang-undang nomor 23 Tahun 2014 Pasal 279 menjelaskan dalam Pasal 279 - Pasal 280 menerangkan kapasitas local dalam pembangunan daerah. Otoritas dimaknai sebagai kewenangan dan kapasitas terhadap urusan konkuren. Selanjutnya diterjemahkan dalam Peraturan Daerah Nomor 141 Tentang Laporan Prosedural dan Pengelolahan Keuangan Daerah Kabupaten Puncak Jaya. Tetapi hasilnya menunjukan bahwa Kabupaten Puncak Jaya belum maksimal memiliki kesadaran penguatan kapasitas pembentuk untuk melahirkan kapasitas lanjutan bagi kemandirian daerah dan kesejahteraan.
\end{abstract}

Kata Kunci: Analisis, Yuridis, Otonomi, Kapasitas, Model

\begin{abstract}
Absract
$T$ The title of the study is an analysis of regional autonomy based local juridical capacity, Study of Financial Management Model and the Regional Asset District of Puncak Jaya. This research background is Puncak Jaya Papua's special autonomy, get a 80\% allocation of special autonomy funds. Puncak Jaya also has abundant natural resources, but a delay in development. The main factor is the system development is not based on local capacity. A legal perspective on local capacity refers to Friedman's theory about the three systems of law, namely the legal aspects of substance, legal structure and legal culture. This research comprehensively look at the three parts are within the scope of Puncak Jaya.This research uses empirisdan juridical technic approach of qualitative analysis, the data source is the legislation on local government, local finance and regional autonomy, regional executive report from authorized agencies, interviews with government authorities and finance at the District Pucak Jaya. Through this method to obtain maximum results and accountability. Law No. 23 Year 2014 Article 279 describes in Article 279 - Article 280 describes local capacity in regional development. Authorities interpreted as the authority and capacity to concurrent affairs. Furthermore translated in Regional Regulation No. 141 About Procedural Report and
\end{abstract}


Financial pengelolahan Puncak Jaya District. But the results showed that the Puncak Jaya has not maximum capacity strengthening awareness-forming to deliver an advanced capacity for the region's autonomy and well-being.

Keyword: Juridical, Analysis, Autonomy, Capacity, Model.

\section{Pendahuluan}

Dalam sistem negara kesatuan Republik Indonesia ditemukan adanya dua cara yang dapat menghubungkan antara pemerintah pusat dan daerah. Cara pertama disebut sentralisasi, yang mana segala urusan, fungsi, tugas, dan wewenang penyelenggaraan pemerintahan ada pada pemerintah pusat yang pelaksanaannya dilakukan secara dekonsentrasi. Cara kedua dikenal sebagai desentralisasi, di mana urusan, tugas dan wewenang pelaksanaan pemerintahan diserahkan seluas-luasnya kepada daerah. ${ }^{1}$

Desentralisasi adalah suatu istilah yang luas dan selalu menyangkut persoalan kekuatan (power), biasanya dihubungkan dengan pendelegasian atau penyerahan wewenang dari pemerintah pusat kepada pejabatnya di daerah atau kepada lembaga-lembaga pemerintah di daerah untuk menjalankan urusan-urusan kembaga-lembaga pemerintahan di daerah. ${ }^{2}$ Tujuan utama desentralisasi adalah 1) tujuan politik, yang ditujukan untuk menyalurkan partisipasi politik di tingkat daerah untuki terwujudnya stabilitas politik nasional ; 2) tujuan ekonomis, yang dimaksud untuk menjamin bahwa pembangunan akan dilaksanakan secara efektif dan efisien di daerah-daerah dalam rangka mewujudkan kesejahteraan sosial. ${ }^{3}$ Sementara itu Syaikani HR mengatakan bahwa desentralisasi adalah sebuah mekanisme penyelenggaraan pemerintahan yang menyangkut pola hubungan antara pemerintahan nasional dan pemerintah lokal. Di dalam mekanisme tersebut, pemerintah nasional melimpahan kewenangan kepada pemerintah lokal. ${ }^{4}$

Kesemua undang-undang mengarahkan bahwa unit pelaksana keuangan daerah yang dilaksanakan Dinas Pengelolaan Keuangan, dan Aset Daerah, Badan Keuangan Daerah, Dinas Pendapatan Daerah, serta kedinasan lainnya dituntut agar mampu mengurus pembiayaan rumah tangga sendiri. Untuk mewujudkan hal tersebut pemerintah daerah harus dapat lebih meningkatkan inisiatif dan kreativitasnya dengan melakukan usaha-usaha yang konkrit dan konstitusional dalam mencari dan menggali terutama pajak dan retribusi daerah. Karena pajak dan retribusi daerah merupakan sumber pendapatan daerah yang penting guna membiayai penyelenggaraan pemerintahan dan pembangunan daerah.

Daerah yang tidak memiliki cukup kapasitas di dalam pengendalian keuangan daerah, berpotensi dapat berimplikasi pada menurunnya kapasitas yang lambat laun akan mengancam fungsi desentralisasi daerah tersebut. Secara umum daerah-daerah di propinsi Papua berada pada kondisi serupa, terlebih lagi adanya kebijakan otonomi khusus, yang memberikan ruang lebih luas dari daerah lain di Indonesia.

Kekhususan otonomi di Papua berlaku bagi kabupaten/kota yang ada di propinsi Papua dan Papua Barat. Salah satunya adalah Kabupaten Puncak Jaya, Beberapa kewenangan khusus yang diberikan dalam kerangka otonomi daerah pun dapat dilakukan oleh pemerintah Kabupaten. Sebagaimanan dipertegas bahwa "Selain kewenangan sebagaimana dimaksud pada ayat (1), dalam rangka pelaksanaan Otonomi Khusus, Provinsi Papua diberi kewenangan khusus berdasarkan Undang-undang ini; "Pelaksanaan kewenangan sebagaimana dimaksud pada ayat (1) dan ayat (2), diatur lebih lanjut dengan Perdasus atau Perdasi”. 5

\footnotetext{
Sarundajang, Arus Balik Kekuasaan Pusat ke Daerah, Pustaka Sinar Harapan, Jakarta, 2000, hlm. 81.

Utung Rosidin. Otonomi Daerah dan Desentralisasi. Pustaka Setia. Bandung. Thn 201086

Ibid -Hlm. 87

H. Saykani. Otonomi Daerah dalam Negara Kesatuan. Pena Publishing. Jakarta. Thn 2000. Hlm. 20

Lihat pasal 4 Undang-undang 21 Tahun 2001 tentang Otonomi Khusus Papua
} 
Provinsi Papua tengah menghadapi tantangan yang sangat besar, tantangan tersebut adalah kesiapan individu dan masyarakat Papua di dalam menghadapi era baru perdagangan bebas. Diketahui bahwa Negara melalui UU Nomor 20/2001 telah memberi ruang presentase dana perimbangan yang sangat besar, dalam hal pembagian hasil pengelolahan sumber daya alam. Pengelolahan sumber daya kehutanan, kelautan, perikanan, pertambangan umum dan khusus. Kesemuanya memberikan kompensasi $80 \%$ bagi Kabupaten-Kabupaten di Papua. Dari total potensi dan gairah eksploitasi yang dikerjakan selama ini menunjukan adanya nilai uang yang tidak sedikit. ${ }^{6}$

J. F. Anderson dalam bukunya Joko Widodo tentang Analisis Kebijakan Publik, mengartikan kebijakan sebagai serangkaian tindakan yang mempunyai tujuan tertentu yang diikuti dan dilaksanakan oleh pelaku atau sekelompok pelaku guna memecahkan masalah tertentu. ${ }^{7}$ Berangkat dari teori ini maka sebenarnya kebijakan yang diperlukan di Kabupaten Puncak Jaya adalah kebijakan menjamin kepastian penyelesaian publik, sudah tentu kebijakan tersebut lahir dari pergumulan masalah demi masalah di masyarakat. Korelasi kebijakan dengan aset dan keuangan adalah fokus pemanfaatannya sebagai alat penyelesaian permasalahan publik. Publik memiliki masalah pengangguran, kemiskinan, tidak tersedia lapangan kerja, rendahnya kompotensi kreatif ekonomi. Maka arah kebijakan keuangan aset itu terarah pada masalahmasalah tersebut.

Permasalahan akuntabilitas keuangan di Papua dan Papua Barat adalah sebagai berikut ; 8 1. Opini atas LKPD 2009 :

a. Belum terdapat LKPD di Wilayah Provinsi Papua dan Papua Barat yang memperoleh Opini WTP.

b. Di Wilayah Provinsi Papua, dari 30 Pemda sebanyak 7 Pemda memperoleh opini WDP, 12 Pemda memperoleh opini TMP dan sisanya sebanyak 11 Pemda belum diketahui hasilnya.

c. Di Wilayah Provinsi Papua Barat, dari 12 Pemda sebanyak 1 Pemda memperoleh opini WDP, 5 Pemda memperoleh opini TMP dan sisanya sebanyak 12 pemda belum diketahui hasilnya.

2. Ketepatan waktu penetapan APBD 2010 :

a. Di Wilayah Provinsi Papua, dari 30 Pemda hanya 12 pemda yang tepat waktu penetapan APBD-nya.

b. Di Wilayah Provinsi Papua Barat, dari 12 Pemda hanya satu pemda yang tepat waktu penetapan APBD-nya yaitu Kabupaten Sorong.

3. Penyerapan Anggaran Tahun 2010 :

4. Penyerapan anggaran per 31 Juli 2010, rata-rata penyerapan anggaran di wilayah Provinsi Papua hanya 27, 41 \% sedangkan di wilayah Provinsi Papua Barat sebesar 28, 16\%.

Laporan BPKP tersebut diatas mengindikasikan adanya problematika dalam pengelolahan keuangan dan aset daerah di kabupaten Puncak Jaya. Sistem pengelolahan yang baik, sudah tentu akan menjadi catatatan bagi rencana pengelolahan keuangan dan asset pada periode selanjutnya. Satu pertanyaan yang mendasari penulisan ini adalah mengapa sumber daya alam yang besar di Papua, ditambah dengan dukungan otonomi khusus, tetapi tidak juga berimplikasi pada kemandirian papua dan kesejahteraan rakyat. Oleh karena itu maka diperlukan sebuah

6 Peraturan Daerah Khusus Provinsi Papua Nomor 25 tahun 2013 tentang pembagian penerimaan dan pengelolaan keuangan dana otonomi khusus. Pasal 8 “(1) Penerimaan Dana Otonomi Khusus setelah dikurangi dengan pembiayaan Prospek dan program strategis lintas kabupaten/kota sebagaimana dimaksud dalam Pasal 7 ayat (1), dibagi dengan proporsi 20\% (dua puluh persen) untuk Provinsi Papua dan 80\% (delapan puluh persen) untuk Kabupaten/Kota se Provinsi Papua. (2) Pembagian Dana Otonomi Khusus sebesar 80\% (delapan puluh persen) sebagaimana dimaksud pada ayat (1) dialokasikan kepada Kabupaten/Kota berdasarkan alokasi dasar dan alokasi variabel.

7 Joko Widodo, Analisis Kebijakan Publik, Banyumedia Publishing, Malang, 2007, hlm. 13.

8 Iman Bastari Laporan BPKP (Badan Pengawasan Keuangan dan Pembangunan), Jakarta. Tahun 2011, 
kajian mendalam serta analisis yang tajam terhadap berbagai dinamika dan sebab-sebab dalam kebijakan dan pelaksanaannya di Kabupaten Puncak Jaya.

Dari persoalan itu, makalah ini akan membahas mengenai dua hal: (1) Bagaimana sistem pengelolahan keuangan dan aset daerah berbasis kapasitas lokal, (2) Apa saja faktor yang mempengaruhi pelaksanaan pengelolahan keuangan dan aset daerah berbasis kapisat lokal?

\section{Metode Penelitian}

Permasalahan yang telah dirumuskan di atas akan dijawab atau dipecahkan dengan menggunakan metode pendekatan yuridis empiris. Pendekatan yuridis (hukum dilihat sebagai norma atau das sollen), karena dalam membahas permasalahan penelitian ini menggunakan bahan-bahan hukum berbentuk peraturan perundang-undangan. ${ }^{9}$ dan Pendekatan empiris (hukum sebagai kenyataan sosial, kultural atau das sein), karena dalam penelitian ini digunakan data primer yang diperoleh dari lapangan. Jadi, pendekatan yuridis empiris dalam penelitian ini maksudnya adalah bahwa dalam menganalisis permasalahan dilakukan dengan cara memadukan bahan-bahan hukum (yang merupakan data sekunder) dengan data primer.

Ada pula pembahasan yang sifatnya sosiologis, terkait soal budaya hukum masyarakat Puncak Jaya, yuridis sosiologis, artinya suatu penelitian yang dilakukan terhadap keadaan nyata masyarakat atau lingkungan masyarakat dengan maksud dan tujuan untuk menemukan fakta (fact-finding), yang kemudian menuju pada identifikasi (problem-identification) dan pada akhirnya menuju kepada penyelesaian masalah (problem-solution). ${ }^{10}$

\section{Hasil Penelitian dan Pembahasan}

\section{Sistem Pengelolaan Keuangan dan Aset Daerah}

Pembangunan berbasis kapasitas merupakan bagian yang penting di dalam otonomi daerah. Kapasitas dipandang sebagai sebuah kemampuan yang diperoleh dari sekian kali proses, dan kemudian bermanfaat bagi rencana lanjutan. Tetapi penulis memiliki pandangan yang lebih meluas tentang Kapasitas Lokal. Kapasitas Lokal merupakan kemampuan dasar yang bekerja secara teratur untuk membentuk kapasitas berikutnya secara berkelanjutan. Pengertian tersebut mengidentikan kapasitas sebagai sebuah modal, bukan sebuah tujuan.

Hukum positif Indonesia sebenarnya telah mengatur tentang lokal kapasitas, secara khusus dalam aspek pengelolahan keuangan, sebenarnya daerah telah memiliki otoritas penuh melakukan pengelolahan dan menetapkan target pencapaiannya sendiri. Undang-undang nomor 23 Tahun 2014 Pasal 279 menjelaskan bahwa :

a. Pasal 279

1) Pemerintah Pusat memiliki hubungan keuangan dengan Daerah untuk membiayai penyelenggaraan Urusan Pemerintahan yang diserahkan dan/atau ditugaskan kepada Daerah.

2) Hubungan keuangan dalam penyelenggaraan Urusan Pemerintahan yang diserahkan kepada Daerah sebagaimana dimaksud pada ayat (1) meliputi:

a) Pemberian sumber penerimaan Daerah berupa pajak daerah dan retribusi daerah;

b) Pemberian dana bersumber dari perimbangan keuangan antara Pemerintah Pusat dan Daerah;

c) Pemberian dana penyelenggaraan otonomi khusus untuk Pemerintahan Daerah tertentu yang ditetapkan dalam undang-undang; dan

d) Pemberian pinjaman dan/atau hibah, dana darurat, dan insentif (fiskal).

3) Hubungan keuangan dalam penyelenggaraan Urusan Pemerintahan yang ditugaskan kepada Daerah sebagaimana dimaksud pada ayat (1) disertai dengan

\footnotetext{
$9 \quad$ Hukum yang tertulis adalah hukum yang dibuat oleh pejabat yang berwenang yang berlaku umum dengan ancaman sanksi yang tegas.

10 Soejono Soekanto, Pengantar Penelitian Hukum, UI Press, Jakarta, 1982, hlm. 10
} 
pendanaan sesuai dengan Urusan Pemerintahan yang ditugaskan sebagai pelaksanaan dari Tugas Pembantuan.

4) Ketentuan lebih lanjut mengenai hubungan keuangan antara Pemerintah Pusat dan Daerah sebagaimana dimaksud pada ayat (2) dan ayat (3) diatur dengan undangundang. Pasal 280... - 149 -

b. Pasal 280

1) Dalam menyelenggarakan sebagian Urusan Pemerintahan yang diserahkan dan/ atau ditugaskan, penyelenggara Pemerintahan Daerah mempunyai kewajiban dalam pengelolaan keuangan Daerah.

2) Kewajiban penyelenggara Pemerintahan Daerah dalam pengelolaan keuangan Daerah sebagaimana dimaksud pada ayat (1) meliputi:

a) Mengelola dana secara efektif, efisien, transparan dan akuntabel;

b) Menyinkronkan pencapaian sasaran program Daerah dalam APBD dengan program Pemerintah Pusat; dan

c) Melaporkan realisasi pendanaan Urusan Pemerintahan yang ditugaskan sebagai pelaksanaan dari Tugas Pembantuan.

Pasal 279 dan 280 UU Nomor 23/ 2014 notabene menjelaskan tentang kapasitas pemerintah dalam pengaturan keuangan daerah. Sementara itu elemen lain dalam penelitian ini adalah tentang aset daerah, dalam pasal 307 UU Nomor 23/ 2014 diuraikan bahwa :

a. Pasal. 307

1) Barang milik daerah yang diperlukan untuk penyelenggaraan urusan pemerintah tidak dapat dipindahtangankan ;

2) Pelaksanaan pengadaan barang milik daerah dilakukan sesuai dengan kemampuan keuangan dan kebutuhan daerah berdasarkan prinsip efisiensi, efektivitas, dan transparansi dengan mengutamakan produk dalam negeri sesuai dengan ketentuan peraturan perundang-undangan.

3) Barang milik daerah yang tidak digunakan untuk penyelenggaraan urusan pemerintah dapat dihapus dari daftar barang milik daerah dengan cara dijual, dipertukarkan, dihibahkan, disertakan sebagai modal daerah, dan/atau dimusnahkan sesuai dengan ketentuan peraturan perundang-undangan.

4) Barang milik daerah sebagaimana dimaksud pada ayat (1) dan ayat (3) tidak dapat dijadikan tanggungan atau digadaikan untuk mendapatkan pinjaman.

Pasal 307 UU Nomor 23/ 2014 tepat menjelaskan tentang aset daerah, baik itu aset bergerak maupun tidak bergerak, yang diperoleh dengan pengadaan atau tidak. Aset daerah merupakan modal daerah untuk dalam proktifitas ekonomi sehingga turut serta memberikan kontribusi terhadap pendapatan asli daerah. Pertanyaan selanjutnya adalah bagaimana Kabupaten Puncak Jaya memanivestasikan prinsip hukum (red- undang-undang) tersebut dalam program riil otonomi daerah. Tentu dimulai dari melihat posisioning daerah dalam hubungannya dengan pemerintah pusat, pada bagian mana saja daerah memiliki kapasitas untuk berbuat dan tidak berbuat.

Kapasitas berbuat dan atau tidak berbuat itu diatur dalam klausul tentang urusan, yang diuraikan dengan sangat jelas dalam UU Nomor 23/2014. Urusan dalam hubungan pemerintah pusat dan daerah mencakup urusan absolut, urusan pemerintah konkuren, dan urusan pemerintah umum. Diantara ketiga urusan tersebut, urusan yang bisa dibagi adalah urusan konkuren. Urusan konkuren diserahkan ke daerah sebagai dasar pelaksanaan otonomi daerah. Selanjutnya tentang hal tersebut diuraikan dalam pasal 11 sebagai berikut :

a. Urusan pemerintah konkuren sebagaimana dimaksud dalam pasal 9 ayat (3) yang menjadi kewenangan daerah terdiri atas urusan pemerintah wajib dan urusan 
pemerintah pilihan;

b. Urusan pemerintah wajib sebagaimana dimaksud pada ayat (1) terdiri dari urusan pemerintah yang berkaitan dengan pelayanan dasar dan urusan pemerintah yang tidak berkaitan dengan pelayanan dasar;

c. Urusan pemerintah wajib yang berkaitan dengan pelayanan dasar sebagaimana dimaksud pada ayat (2) adalah urusan pemerintah wajib yang sebagaimaan susbtansinya merupakan pelayanan dasar.

Berikut ini adalah daftar urusan konkuren berdasarkan pada undang-undang nomor 23 tahun 2014 pasal 12, sebagai berikut :

\begin{tabular}{|c|c|}
\hline Wajib Pelayanan Dasar & Wajib Bukan Pelayanan Dasar \\
\hline Pendidikan & Tenaga kerja \\
\hline Kesehatan & $\begin{array}{lll}\text { Pemberdayaan } & \text { perempuan } \\
\text { perlindungan anak } & & \end{array}$ \\
\hline Perkejaan umum dan penataan ruang & Pangan \\
\hline Perumahan rakyat dan kawasan pemukiman & Pertanahan \\
\hline $\begin{array}{l}\text { Ketentraman, ketetriban umum dan } \\
\text { perlindungan masyarajat }\end{array}$ & Lingkungan hidup \\
\hline 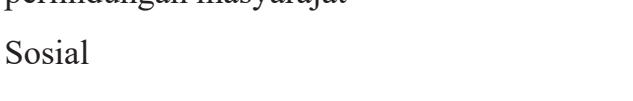 & $\begin{array}{l}\text { Administrasi kependudukan dan cararan } \\
\text { sipul }\end{array}$ \\
\hline & Pemberdayaan masyarakat dan desa \\
\hline Urusan Pilihan & $\begin{array}{l}\text { Pengendalian penduduk dan keluarga } \\
\text { berencana }\end{array}$ \\
\hline Kelautan dan perikanan & Perhubungan \\
\hline Pariwisata & Komunikasi dan informasi \\
\hline Pertanian & Koperasi dan usaha kecil menengah \\
\hline Kehutanan & Penanaman modal \\
\hline Energi dan sumber daya mineral & Kepemudaan dan olahraga \\
\hline Perdagangan & Statistik \\
\hline Perindustrian & Persandian \\
\hline \multirow[t]{3}{*}{ Transmigrasi } & Kebudayaan \\
\hline & Kepustakaan \\
\hline & Kearsipan \\
\hline
\end{tabular}

2. Pelaksanaan Pengelolaan Keuangan dan Aset Daerah di Kabupaten Puncak Jaya

\section{a. Ruang Lingkup Pengelolaan Keuangan Daerah}

Berdasarkan ketentuan Pasal 330 Peraturan Menteri Dalam Negeri Nomor 13 Tahun 2006 yang beberapa kali diubah terakhir dengan Peraturan Menteri Dalam Negeri Nomor 21 Tahun 2011 Tentang Pengelolaan Keuangan Daerah, Sistem dan Prosedur Pengelolaan Keuangan Daerah diatur dengan Peraturan Bupati. Oleh karena itu maka setiap Bupati diwajibkan oleh undang-undang untuk menerbitkan Peraturan Daerah ${ }^{11}$ yang mana ide dasarnya tentang beberapa hal terkait pengelolahan keuangan darah. Hal-hal tersebut antara lain mencakup Perencanaan anggaran, Pelaksanaan belanja anggaran, dan Pelaporan keuangan daerah. ${ }^{12}$

11 Peraturan Daerah adalah peraturan perundang-undangan yang dibentuk DPRD dengan persetujuan bersama Kepala Daerah. (Perda. Kab. Puncak Jaya : Perda 141/20

12 Entitas laporan adalah unit pemerintahan yang terdiri atas satu atau lebih entitas akuntansi yang menurut ketentuan pera- 
Selama tahun 2013, Pemerintah Daerah Puncak Jaya telah melakukan kegiatan belanja, yang mana sumber uangnya berasal dari pemerintah pusat, pendapatan daerah ${ }^{13}$ dan sumbangan lainnya. Sumber keuangan ${ }^{14}$ dari daerah salah satunya berasal dari pengelolahan dan pemanfaatan aset daerah.

Keuangan daerah yang terkelola di Kabupaten Puncak Jaya meliputi enam komponen, yaitu $:^{15}$

1) Hak daerah untuk memungut pajak daerah dan retribusi daerah serta melakukan pinjaman dan menerima pendapatan bunga dari deposito dana di bank.

2) Kewajiban daerah untuk menyelenggarakan urusan pemerintahan daerah dan membayar tagihan pihak ketiga.

3) Penerimaan daerah

4) Pengeluaran daerah

5) Kekayaan daerah yang dikelola sendiri atau oleh pihak lain berupa uang, surat berharga, piutang, barang, serta hak-hak lain yang dapat dinilai dengan uang, termasuk kekayaan yang dipisahkan pada perusahaan daerah.

6) Kekayaan pihak lain yang dikuasi oleh pemerintah daerah dalam rangka penyelenggaraan tugas pemerintah daerah dan/atau kepentingan umum.

Pengelolahan keuangan dan aset daerah di Kabupaten Puncak Jaya selama ini mengacu pada Peraturan Pemerintah (PP) Nomor 58 Tahun 2005 dan Peraturan Menteri Dalam Negeri Nomor 13 tahun 2006 sebagaimana telah diubah beberapa kali, terakhir dengan Permendagri Nomor 21 Tahun 2011 tentang Pengelolaan Keuangan Daerah, Permendagri Nomor 64 Tahun 2013 dan Peraturan Pemerintah Nomor 71 Tahun 2010 tentang Standar Akuntansi Pemerintahan. Perubahan ini memperlihatkan sebuah paradigma yaitu pengelolaan keuangan daerah yang lebih baik karena apabila peraturan pemerintah dan peraturan menteri tersebut dijalankan dalam pengelolaan keuangan daerah, maka akan terdapat sinkronisasi antara kebijakan pusat dan daerah, juga terintegrasinya perencanaan dan penganggaran daerah. ${ }^{16}$

Selain dua penyebab penting di atas, sebetulnya kemampuan leadership dari pemimpin dalam mensosialisasikan perubahan dan mendorong aparat untuk mengikuti perubahan, merupakan faktor yang jauh lebih penting. Oleh karena itu, sistem dan prosedur pengelolaan keuangan daerah sebagai sebuah simplifikasi Peraturan Menteri Dalam Negeri Nomor 13 Tahun 2006, Peraturan Menteri Dalam Negeri Nomor 59 Tahun 2007, Peraturan Menteri Dalam Negeri Nomor 21 Tahun 2011 dan Peraturan Menteri Dalam Negeri Nomor 64 Tahun 2013 ini diharapkan mampu menjadi salah satu pemecahan bagi masalah tersebut di atas. Artinya, dengan Simplifikasi Sistem dan Prosedur ini, diharapkan akan mempermudah aparat atau pelaksanaan di lapangan untuk mengimplementasikan aturan baru yang dikeluarkan pemerintah mengenai pengelolaan keuangan daerah ini. ${ }^{17}$

Kajian tentang praktik pengelolahan keuangan di Kabupaten Puncak Jaya mencakup tiga bagian besar, yaitu; instrumen elemen pengelolah, struktur APBD (anggaran pendapatan

turan perundang-undangan wajib menyampaikan laporan pertanggungjawaban berupa laporan keuangan. (Perda. Kab. Puncak Jaya : Perda 141/2004)

13 Anggaran Pendapatan dan Belanja Daerah yang selanjutnya disebut APBD adalah rencana keuangan tahunan pemerintahan daerah yang dibahas dan disetujui bersama oleh Pemerintah Daerah dan Dewan Perwakilan Rakyat Daerah yang masa berlakunya dari tanggal 1 Januari sampai dengan 31 Desember tahun berkenaan dan ditetapkan dengan Peraturan Daerah. (Perda. Kab. Puncak Jaya : Perda 141/2004)

14 Keuangan Daerah adalah semua hak dan kewajiban daerah dalam rangka penyelenggaraan pemerintah daerah yang dapat dinilai dengan uang termasuk didalamnya segala bentuk kekayaan yang berhubungan dengan hak dan kewajiban daerah tersebut. (Perda. Kab. Puncak Jaya : Perda 141/2004)

15 Perda Kabupaten Puncak Jaya 141/2004; Pasal. 2

16 Wawancara dengan Syamsuddin Roma, S. Sos, Selaku Kepala DPKAD Kabupaten Puncak Jaya. Pada tanggal 28 Juli 2015

17 Ibid Wawancara 
\& belanja daerah), pertanggungjawaban, pembinaan dan pengawasan, pengendalian dan monitoring, tuntutan perbendaharaan dan tuntutan ganti rugi.

\section{b. Struktur APBD (Anggaran Pendapatan dan Belanja Daerah)}

Pendapatan daerah meliputi semua penerimaan uang melalui rekening kas umum daerah, yang menambah ekuitas dana, merupakan hak daerah dalam satu tahun anggaran dan tidak perlu dibayar kembali oleh daerah. Pendapatan daerah dirinci menurut urusan pemerintahan daerah, organisasi, kelompok, jenis, obyek dan rincian obyek pendapatan. Struktur APBD di Kabupaten Puncak Jaya mengacu pada ketentuan sebagaimana di atur dalam UU Nomor 23 Tahun 2014 tentang pemerintahan daerah dan juga UU Nomor 33 Tahun 2004 tentang perimbangan keuangan pusat dan daerah. ${ }^{18}$

1) Realisasi Pendapatan Daerah Kabupaten Puncak Jaya

Realisasi pendapatan sampai dengan Tahun Anggaran 2013 berakhir seluruhnya berjumlah $\mathrm{Rp} 833.221 .975 .494,00$ atau $90,15 \%$ dari total anggaran pendapatan yang dialokasikan dalam Anggaran Pendapatan dan Belanja Daerah sebesar Rp 924.246.934.677,00. Realisasi Pendapatan Asli Daerah sampai dengan akhir Tahun Anggaran 2013 seluruhnya Rp 5.120.872.091,00 dari total pendapatan yang terealisasi Rp 833.221.975.494,00 atau 0,61\%. Pendapatan asli daerah tersebut terdiri dari :

Tabel 1. Realisasi Pendapatan Asli Daerah Tahun Anggaran 2013

\begin{tabular}{lcccc}
\hline \multicolumn{1}{c}{ Jenis PAD } & Target PAD & Realisasi PAD & Lebih (kurang) & \% \\
\hline Pen - Pajak & 299.798 .425 & 232.202 .500 & 67.595 .925 & 77,45 \\
Pen - Retribusi & 120.033 .155 & 1.152 .831 .317 & 117.201 .838 & 90,77 \\
$\begin{array}{l}\text { Pen-kelolah lekayaan asli } \\
\text { daerah yang dipisahkan }\end{array}$ & 3.355 .168 .431 & 3.255 .168 .431 & 100.000 .000 & 97,02 \\
Lain-lain PAD yang sah & 4.721 .928 .367 & 480.669 .843 & 4.241 .258 .524 & 10,18 \\
Jumlah & 9.646 .928 .378 & 5.120 .872 .091 & 4.526 .056 .287 & 53,08 \\
\hline
\end{tabular}

Realisasi Pendapatan Transfer Pemerintah Pusat sampai dengan akhir Tahun Anggaran 2013 seluruhnya Rp 769.740.942.578,00 dari total pendapatan yang terealisasi Rp 833.221.975.494,00 atau 92,67\%. Pendapatan Transfer Pemerintah Pusat tersebut terdiri dari :

Tabel 2. Realisasi Pendapatan Transfer Pemerintah Pusat Tahun Anggaran 2013

\begin{tabular}{lcccc}
\hline \multicolumn{1}{c}{ Jenis } & Target & Realisasi & Lebih (Kurang) & \% \\
\hline $\begin{array}{l}\text { Dana Bag Hasil } \\
\text { Pajak }\end{array}$ & 23.509 .954 .619 & 24.052 .604 .689 & 542.650 .070 & 102,31 \\
$\begin{array}{l}\text { Dana Bag Hasil } \\
\text { Sumber Daya }\end{array}$ & 13.286 .419 .889 & 13.286 .419 .889 & 100,00 \\
Alam & & & \\
$\begin{array}{l}\text { Dana Alokasi } \\
\text { Umum }\end{array}$ & 533.372 .754 .000 & 533.372 .754 .000 & 100,00 \\
$\begin{array}{l}\text { Dana Alokasi } \\
\text { Khusus }\end{array}$ & 113.752 .860 .000 & 113.752 .860 .000 & & 100,00 \\
$\begin{array}{l}\text { Dana Otonomi } \\
\text { Khusus }\end{array}$ & 120.482 .357 .000 & 83.873 .357 .000 & $(36.609 .000 .000)$, & 69.61 \\
\hline
\end{tabular}




\begin{tabular}{lcccc}
\hline \multicolumn{1}{c}{ Jenis } & Target & Realisasi & Lebih (Kurang) & \% \\
\hline $\begin{array}{l}\text { Dana Tunjangan } \\
\text { Pendidikan }\end{array}$ & 1.402 .947 .000 & 1.402 .947 .000 & & \\
Jumlah & $805.807 .292 .508,00$ & 769.740 .942 .578 & $(36.066 .349 .930)$, & 95,52 \\
\hline
\end{tabular}

Realisasi Pendapatan Transfer Pemerintah Provinsi sampai dengan akhir Tahun Anggaran 2013 seluruhnya Rp 2.402.150.190,00 dari total Pendapatan yang terealisasi Rp 833.221.975.494,00 atau 0,29\%. Pendapatan Transfer Pemerintah Provinsi tersebut terdiri dari:

Tabel 3. Realisasi Pendapatan Transfer Pemerintah Provinsi Tahun Anggaran 2013

\begin{tabular}{lcccc}
\hline \multicolumn{1}{c}{ Jenis } & Target & Realisasi & Lebih (kurang) & \% \\
\hline $\begin{array}{l}\text { Pendapatan Bagi } \\
\text { Hasil Pajak }\end{array}$ & 594.902 .307 & 2.402 .150 .190 & 1.807 .247 .883 & 403,79 \\
$\begin{array}{l}\text { Pendapatan Bagi } \\
\text { Hasil Lainnya }\end{array}$ & & & & \\
Jumlah & 594.902 .307 & 2.402 .150 .190 & 1.807 .247 .883 & 403,79 \\
\hline
\end{tabular}

Realisasi lain-lain pendapatan yang sah sampai dengan akhir Tahun Anggaran 2013 seluruhnya $\mathrm{Rp} 55.958 .00 .635,00$ dari total pendapatan yang terealisasi $\mathrm{Rp}$ 833.221.975.494,00 atau 6,72\%. Lain-lain pendapatan yang sah tersebut terdiri dari :

Tabel 4. Realisasi Lain-lain Pendapatan yang Sah Tahun Anggaran 2013

\begin{tabular}{lcccc}
\hline \multicolumn{1}{c}{ Jenis } & Target & Realisasi & Lebih (kurang) & \% \\
\hline Bantuan Keuangan dari & 92.875 .250 .000 & 47.875 .250 .000 & 45.000 .000 .000 & 51,55 \\
Provinsi & 15.322 .561 .484 & 8.082 .760 .635 & 7.239 .800 .849 & 52,75 \\
Pendapatan Lain-lain & 108.197 .811 .484 & 55.958 .010 .635 & 52.239 .800 .849 & 51,72 \\
Jumlah & & & \\
\hline
\end{tabular}

Tabel 5. Realisasi Pendapatan Transfer Pemerintah Provinsi Tahun Anggaran 2013

\begin{tabular}{lcccc}
\hline \multicolumn{1}{c}{ Jenis } & Target & Realisasi & Lebih (kurang) & \% \\
\hline $\begin{array}{l}\text { Pendapatan Bagi } \\
\text { Hasil Pajak }\end{array}$ & 594.902 .307 & 2.402 .150 .190 & 1.807 .247 .883 & 403,79 \\
$\begin{array}{l}\text { Pendapatan Bagi } \\
\text { Hasil Lainnya }\end{array}$ & & & & \\
Jumlah & 594.902 .307 & 2.402 .150 .190 & 1.807 .247 .883 & 403,79 \\
\hline
\end{tabular}

Realisasi lain-lain pendapatan yang sah sampai dengan akhir Tahun Anggaran 2013 seluruhnya $\mathrm{Rp} 55.958 .00 .635,00$ dari total pendapatan yang terealisasi $\mathrm{Rp}$ 833.221.975.494,00 atau 6,72\%. Lain-lain pendapatan yang sah tersebut terdiri dari :

Tabel 6. Realisasi Lain-lain Pendapatan yang Sah Tahun Anggaran 2013

\begin{tabular}{lcccc}
\hline \multicolumn{1}{c}{ Jenis } & Target & Realisasi & Lebih (kurang) & $\%$ \\
\hline $\begin{array}{l}\text { Bantuan Keuangan dari } \\
\text { Provinsi }\end{array}$ & 92.875 .250 .000 & 47.875 .250 .000 & 45.000 .000 .000 & 51,55 \\
\hline
\end{tabular}




\begin{tabular}{lcccc}
\hline \multicolumn{1}{c}{ Jenis } & Target & Realisasi & Lebih (kurang) & \% \\
\hline Pendapatan Lain-lain & 15.322 .561 .484 & 8.082 .760 .635 & 7.239 .800 .849 & 52,75 \\
\multirow{2}{*}{ Jumlah } & 108.197 .811 .484 & 55.958 .010 .635 & 52.239 .800 .849 & 51,72 \\
\hline
\end{tabular}

3. Faktor-Faktor yang Mempengaruhi Pengelolaan Keuangan dan Aset Daerah Berbasis Kapasitas Lokal

\section{a. Faktor Hukum}

Peraturan hukum yang mengatur tentang kajian ini adalah perundang-undangan yang mengatur tentang pemerintah daerah, perimbangan keuangan pusat dan daerah, pengelolahan keungan daerah. Sebenarnya pada tataran substansi telah diatur bahwa daerah memiliki kapasitas secara konstitusi untuk mengatur diri sendiri, dengan tetap memperhatikan ketentuan-ketentuan lain dalam hubungan pemerintah pusat dan daerah. Sekalipun peraturan hukum tersebut telah mengatur sedemikian rupa tentang otonomi daerah, agar otonomisasi bisa memberikan dampak positif bagi kemandirian daerah dan kesejahteraan rakyat, tetapi tujuan itu terasa sulit untuk dicapai.

Terlihat dengan sangat jelas bahwa setelah sekian tahun Kabupaten Puncak Jaya mendapatkan kepercayaan negara untuk menjadi daerah otonomi, faktanya Kabupaten Puncak Jaya belum beranjak dari kondisi minimalis dalam Pendapatan Asli Daerah. Hal tersebut menunjukan bahwa peraturan demi peraturan, baik undang-undang, pertauran mentri, putusan dan instruksi presiden, dan peraturan daerah sekalipun belum mampu mendongkrak pembangunan di Kabupaten Puncak Jaya.

Konstruksifikasi hukum terhadap pembangnan di Kabupaten Puncak Jaya lazimnya mencakup hukum nasional sebagaimana undang-undang, peraturan mentri, dan peraturan daerah. Tetapi selain itu juga ada hukum adat masyarakat papua yang mengikat dalam beberapa urusan tertentu. Dari hal tersebut sebenarnya Kabupaten Puncak Jaya memiliki kekuatan substansi yang sangat besar, karena kedua hukum tersebut berlaku secara bersamasama. Dari kondisi tersebut juga sebenarnya menjadi alasan percepatan pembangunan di Kabupaten Puncak Jaya. Namun lagi-lagi kenyataan tidak seperti yang diharapkan.

\section{b. Faktor Kinerja Pemerintah Daerah}

Sebagaimana teori yang disampaikan oleh Friedmen tentang struktur hukum, dimana organ negara yang menjalankan hukum. Makna perluasan yang penulis ungkapkan pada bab sebelumnya, yaitu organ negara pelaksana hukum tidak hanya polisi, jaksa dan pengadilan, tetapi organ tersebut berlaku untuk semua pejabat dan penyelenggara negara yang dipilih dan diangkat secara permanen dalam Pejabat Sipil Nasional, Pejabat Sipil Polisi dan TNI, dan ada pula penyelenggara lain yang dipilih dari pemilihan umum seperti DPRD, DPD serta pihak-pihak yang ditugaskan dan digaji dari uang negara untuk berbuat demi negara. Keterlibatan organ negara sebagai pelaksana hukum tergantung pada bidang tugas dan tanggungjawab masing-masing sesuai dengan peraturan perundang-undangan yang berlaku.

Daerah membutuhkan kepemimpinan yang tangguh, memiliki visi jauh ke depan dan memiliki kemampuan memotret kondisi sosial ekonomi daerahnya di tengah arus otonomi. Pemekaran tidak seharusnya diinterpretasikan sebagai pembagian kekuasaan atau pelimpahan kewenangan semata, apalagi dipergunakan untuk mewadahi kepentingan kelompok sendir. ${ }^{19}$

19 Yusuf Wally. Percepatan Pembangunan dan Kemandirian Kampung. BPFE Yogyakarta. Thn. 2013. Hlm. IV 
Pemerintah daerah mencakup Bupati dan semua jajaran dalam lingkaran SKPD atau non SKPD, serta Dewan Perwakilan Daerah merupakan bagian dari struktur hukum otonomi daerah. Maka beban tanggungjawab pelaksanaan program otonomi daerah berada pada organ-organ tersebut. Penelitian ini menemukan bahwa notabene para pejabat dan penyelenggara pemerintahan daerah di Kabupaten Puncak Jaya terperangkap dalam ruang kosong peraturan perundang-undangan sebagaimana diterangkan pada poin pertama. Lemahnya sumber daya manusia kepala daerah, jajaran kuasa anggaran dan jajaran pelaksana anggaran terlihat dari tidak adanya inisiatif untuk mengelolah keuangan daerah secara lebih profesional yang berdampak out-come bagi daerah. Penelitian ini tidak menelisik secara sepihak pada jabatan tertentu, tetapi melihat secara kolektif, dimana problem mendasar terdapat pada lemahnya kepemimpinan daerah.

Kelemahan pemerintah daerah rendahnya prestasi melahirkan kinerja pengelolahan keuangan dan aset daerah yang berdampak positif pada majunya kesejahteraan anggota masyarakat, meningkatnya nilai PAD hingga bisa memenuhi $25 \%$ total belanja tahunan, terlaksana layanan publik dengan baik dan profesional. Penulis mencoba memberikan standarisasi sebagai berikut ;

1) Pendapatan asli lebih besar $25 \%$ dari pendapatan dana perimbangan

2) Praktek belanja wajib dan pilihan (strategus) lebih besar $45 \%$ dari belanja fungsional, urusan program daerah.

3) Tidak ada praktek korupsi dan kolusi dalam pengelolahan keuangan dan aset daerah

4) Ketersediaan fasilitas bagi publik untuk mengakses kebijakan anggaran dalam rangka pengawasan dan monitoring.

Maka faktor struktur pemerintahan daerah sebagai organ negara di dalam mensejahterakan rakyat dan kemandirian daerah perlu diperkuat. Untuk mendorong lahirnya kapasitas pembentuk dalam pengelolahan keuangan dan aset daerah maka diperlukan perubahan - perubahan managemen pada tata laksana pemerintah daerah, terutama mencakup dua hal yaitu aspek alokasi belanja dan proporsionalitas SDM pejabat dan penyelenggara daerah.

\section{Penutup}

\section{Kesimpulan}

\section{a. Sistem pengelolaan keuangan dan aset daerah}

Hukum positif Indonesia sebenarnya telah mengatur tentang lokal kapasitas, secara khusus dalam aspek pengelolaan keuangan, sebenarnya daerah telah memiliki otoritas penuh melakukan pengelolaan dan menetapkan target pencapaiannya sendiri. Undangundang nomor 23 Tahun 2014 Pasal 279 menjelaskan dalam Pasal 279 - Pasal 280

Rincian tugas dan kewenangan pemerintah pusat dan daerah dalam konteks otonomi daerah, diatur dalam UU Nomor 23/ 2014. Kewenangan terhadap urusan-urusan, dalam hubungan pemerintah pusat dan daerah mencakup urusan absolut, urusan pemerintah konkuren, dan urusan pemerintah umum. Diantara ketiga urusan tersebut, urusan yang bisa dibagi adalah urusan konkuren. Urusan konkuren diserahkan ke daerah sebagai dasar pelaksanaan otonomi daerah

\section{b. Pelaksanaan Pengelolaan Keuangan dan Aset Daerah di Kabupaten Puncak Jaya}

Pengelolahan keuangan dan aset daerah di Kabupaten Puncak Jaya selama ini mengacu pada Peraturan Pemerintah (PP) Nomor 58 Tahun 2005 dan Peraturan Menteri Dalam Negeri Nomor 13 tahun 2006 sebagaimana telah diubah beberapa kali, terakhir dengan 
Permendagri Nomor 21 Tahun 2011 tentang Pengelolaan Keuangan Daerah, Permendagri Nomor 64 Tahun 2013 dan Peraturan Pemerintah Nomor 71 Tahun 2010 tentang Standar Akuntansi Pemerintahan. Secara keseluruhan pelaksanaan pengelolahan keuangan dalam diatur dalam Peraturan Daerah Nomor 141 Tentang Laporan Prosedural dan Pengelolahan Keuangan Daerah Kabupaten Puncak Jaya. Di dalam Perda tersebut diatur sangat terperinci mengenai Struktur APBD (anggaran pendapatan \& belanja daerah); Realisasi Pendapatan daerah Kabupaten Puncak Jaya. Belanja Daerah ; Belanja Operasi, Belanja Modal, Belanja Tak Terduga. Pembiayaan; Penerimaan Pembiayaan, Pengeluaran Pembiayaan.

Hambatan dan Kendala yang Ada dalam Pencapaian Target yang Telah Ditetapkan, Kendala transportasi darat sangat terbatas yang menghubungkan antar distrik dan sangat tergantung pada transportasi udara, selain itu juga kendala dalam hal stabilitas keamanan. Sementara itu aspek Pertangggungjawaban meliputi serangkaian proses identifikasi, pencatatan, pengikhtisaran dan pelaporan keuangan dalam rangka pertanggungjawaban pelaksanaan APBD.

\section{c. Faktor-Faktor yang Mempengaruhi Pengelolaan Keuangan dan Aset Daerah Berbasis Kapasitas Lokal}

Hukum telah memberikan pengaruh terhadap pembangunan di Kabupaten Puncak Jaya, Melalui peraturan perundang-undangan yang ada telah mendorong pentertiban tata kelolah keuangan di Kabupaten Puncak Jaya dimulai. Namun demikian ada ruang kosong dalam peraturan perundang-undangan yang menyebabkan kelambanan pelaksanaan pembangunan di daerah. Ruang kosong tersebut adalah tidak adanya ketentuan dalam peraturan perundang-undangan yang mengatur tentang ukuran keberhasilan yang berlaku wajib bagi pemerintah daerah. Sebagian besar dari ketentuan di dalam peraturan perundangundangan hanya mengatur tentang prosedural dan tata laksana administratif. Itulah yang menyebabkan pelaksanaan/ atau pengelolahan keuangan dan aset di Kabupaten Puncak Jaya sebatas memenuhi unsur pengaturan tersebut, tanpa mempedulikan indeks prestasi bagi kemandirian daerah dan kesejahteraan rakyat.

\section{Saran}

a. Setelah memperhatikan dan menimbang bahwa setiap daerah memiliki problematika berbeda-beda, dalam hal geografis, demografis dan psikografis. Maka sebaiknya Pemerintah Pusat bersama-sama dengan Dewan Perwakilan Rakyat melakukan perubahan terhadap UU Pemerintahan Daerah, UU tentang sistem keuangan daerah dan pusat, UU tentang otonomi daerah, UU tentang Dewan Perwakilan Daerah ; yang lebih menitik beratkan pada ketentuan tentang kewenangan daerah untuk menyusun prosedur kapasitas pembentuk berupa memilih dan mengangkat sejumlah kepala SKPD melalui mekanisme lelang jabatan.

b. Kabupaten Puncak Jaya dan umumnya Kabupaten lain di Provinsi Papua, pada dasarnya menghadapi problematika yang sama yaitu masih terbatasnya sumber daya manusia.

c. Langkah awal untuk menentukan seberapa besar kapasitas pembentuk yang dimiliki oleh Kabupaten Puncak Jaya, maka penulis menyarankan pula perlu dilakukan audit aset dan sumber daya manusia di Kabupaten Puncak Jaya.

\section{Daftar Pustaka}

Bastari, Iman. 2013. Laporan BPKP (Badan Pengawasan Keuangan dan Pembangunan). Jakarta.

Sarundajang, 2000. Arus Balik Kekuasaan Pusat ke Daerah, Jakarta : Pustaka Sinar Harapan. 
Soekanto, Soejono. 1982. Pengantar Penelitian Hukum, Jakarta: UI Press.

Rosidin, Utung. 2010. Otonomi Daerah dan Desentralisasi. Bandung: Pustaka Setia.

Saykani, H. 2000. Otonomi Daerah dalam Negara Kesatuan. Jakarta: Pena Publishing.

Wally, Yusuf. 2013. Percepatan Pembangunan dan Kemandirian Kampung. Yogyakarta: BPFE Yogyakarta.

Widodo, Joko. 2007. Analisis Kebijakan Publik. Malang: Banyumedia Publishing. 